\title{
Identification of the Strengths and Weaknesses of the Conventional and Islamic Financial System during the COVID-19 Pandemic
}

\author{
Amra Nuhanović, Ph. D \\ Faculty of Economics, University of Tuzla \\ Email: amra.nuhanovic [AT] untz.ba
}

\begin{abstract}
In October 2020, the number of fpeople infected with the corona virus reached cumulatively 2 million cases and over 130,000 deaths, which shows that the economic implications of the pandemic crisis continue to complicate the economic and financial situation of the global financial system and national systems. Everything points to the fact that the virus will continue to persist. With the continuous expansion in Africa, Asia, Latin America, but also Islamic countries, the same economies are trying to stop the consequences that the COVID-19 pandemic brings with it. Accordingly, the subject of the research is to identify the strengths and weaknesses of the conventional versus Islamic financial system at the time of COVID-19. Having in mind the above, the main goal of the study is to investigate and identify the Strengths and Weaknesses of the Conventional and Islamic Financial System during the Covid Pandemic -19. The author came to the conclusion that during the global financial crisis of 2008 and the time of the pandemic of December 2019, the Islamic financial system showed better performance, in terms of better protection against certain risks and the fact that financial activities and business financial market are conducted in compliance with Sharia principles. Also, the author is of the opinion that if we overcome this crisis, we must learn and work both in terms of potential preventive measures against the pandemic, and in improving sustainable economic development before it is too late, whether it was a conventional financial system or Islamic. Secondarydata collected from relevant sources will be used (desk research). In addition, other methods stand out: methods of analysis and synthesis, generalization and abstraction, methods of systematized approach (holistic approach), classification and comparison, and methods of induction
\end{abstract}

Keywords--- conventionaleconomics, Islamic economics and finance, COVID-19

\section{INTRODUCTION}

The recent outbreak of COVID-19 has posed a huge challenge to economic res earchers and financial analysts to find an adequate solution to the current situation. A complete economic "shutdown" has created problems such as shocks to world supply and demand which resonate with the global economy. For example, the manufacturing industry reduces production, employees lose their jobs, and face cash flow constraints. Governments are struggling to protect employment and people's livelihoods to reduce negative impacts.

In a rapidly changing environment, it is very difficult to meas ure the real impacts on the globaleconomy by the COVID19 pandemic (meaning primarily the level of production, employment, food security, poverty, international trade, etc.). The countries most affected by the pandemic make up the majority of globalGDP. However, it is important to point out the very important fact that, contrary to the recent global financial cris is, the current pandemic and the current health crisis have affected almost all the world's economies.

To combat the pandemic, many governments have announced incentive packages to channel funding to citizens so that they have funds they can spend even if they are not working. However, there is a fear among Western capitalis teconomists about such government interventions, given that simplified interest-based borrowing can create a debt trap for households and businesses in the long run, which will negatively affect the global economic system.

On the other hand, Is lamic finance is such a sy stemthat functions without interest, and which is claimed to be responsible, ethical, and sustainable and to protect the Is lamic economy frompotential shocks. As is well known, Is lamic finance has proven to be quite resilient in the wake of the 2008-09 global financial crisis. Due to the nature of its products and instruments, which offer a balanced solution for directing funds to end us ers, but not for increasing debt levels. ${ }^{1}$

${ }^{1}$ Is lamic social finance (i.e., Waqf, Zakat, and Is lamic microfinance) can help ensure productivity, while, for example, Sukuk can help the government raise sufficient funds for further dis tribution and other purposes. 
Islamic finance today inevitably represents an alternative to the conventional way of financing the various gaps we see and which we have witnessed to this day. With the increasing use and utilization of Is lamic tools for social financing, such as Waqfs (Islamic endowments) in finance and grosso modo in the economy, greater contributions can be made in order to achieve poverty reduction and promote common prosperity in a sustainable way.

However, since the beginning of the COVID-19 crisis, Is lamic countries (OIC member countries) ${ }^{2}$ have made enormous efforts to intensify joint action in the face of the pandemic, both from an economic, social and legal point of view. The results of such sessions were reflected in initiatives (also s upported by international financial institutions) in the allocation of funds to member states to combat the global effects of the corona virus pandemic and its economic and social impacts. Thus, the financial support of USD 2.3 billion by the ISDB (Islamic Development Bank) as well as the ISF emergency fund of USD 1 million exclusively for ass is tance to the leas t developed Is lamic countries stands out.

Unfortunately, the pandemic has affected all economic sectors and all segments of the population. The rising rates of economic growth that preceded the outbreak of the pandemic are being questioned today. Unemployment and poverty rates are projected to rise dramatically around the world, and many Is lamic countries are unfortunately at the center of these negative implications. In this regard, the current situation in Islamic countries shows that the pandemic has proved particularly harmful to vulnerable social groups in society, including the poor, the elderly, women, youth and children. and persons with dis abilities. People without access to running water, refugees, or migrants dis placed persons suffer and are at ris $\mathrm{k}$ of a pandemic and its consequences in terms of limited mobility, fewer employment opportunities, conflict, conflict, increased xenophobia, preju dice and intolerance. Having in mind the above, the maingoalofthe study is to investigate and identify the Strengths and Weaknesses of the Conventional and Islamic FinancialSystemduring theCovid Pandemic -19.

The paper is divided as follows. After introductory considerations, the second chapter provides a concise overview of the literature and previous research that addresses this is sue. The third chapter is the research methodology, and the fourth is results and interpretation. Finally, the concluding remarks summarize the basic findings and suggestions for future research.

\section{PREVIOUS RESEARCH}

The OECD Interim Economic As sessment for 2020 provides an overview of current trends and thecurrent economic and financial situation in the world economy at the time of COVID 19. Global economic perspectives are still uncertain. The negative implications of the pandemic include, among other things, a sharp decline in economic growth, direct dis ruption and imbalances in global supply chains, a decline in global demand for imported goods and services and a decline in international tourism, a sharp drop in world financial market prices, the decline in confidence in financial activities, the decline in trust of citizens - sufferers, etc. (OECD, 2020)

OIC Economic Outlook 2019, i.e. in the report published in the Statistical, Economic and Social Centre for Res earch and Training for Is lamic Countries (Statistical, Economic and Social Research and Training Centre for Is lamic Countries (SESRIC), for Is lamic countries, are achieved \$ 20.6 trillion in GDP, or $15.2 \%$ of total world production, in $2018 .{ }^{3}$ However, the report states that the financial sector of Islamic countries is very "shallow", with an unemployment rate of $6 \%$, a sharp deterioration in the fiscal balance, etc. (OICEconomic Outlook 2019)

Chattha (2020), with the help of the Toronto Centre Note, presented a study on The Covid-19 Pandemic: Supervisory Implications and Priorities for Is lamic Banking. Chattha considers six potential implications and priorities for supervisors, which regulate Is lamic banks, in response to the COVID-19 pandemic: 1) ensuring transparency, clarity in regulatory interventions and a level playing field for all Is lamic banks; 2) ass et quality management of Is lamic banks, and treatment of moratoriums and poor financing; 3) dealing with liquidity shortages and providing liqu idity support in accordance with Sharia; 4) providing support for the is suance of the state Sukuk for fiscal deficits; 5) credit quality as sessment; and 6) reviewing financial security networks and insolvency regimes for Is lamic banks. (Chattha, 2020)

\footnotetext{
${ }^{2}$ These are coun tries classified as "developing countries", with 21 of them clas sified as "least developed countries". Source: IMF WEO Databases.

${ }^{3}$ Algeria, Azerbaijan, Bahrain, Brunei Darussalam, Gabon, Iran, Iraq, Kazakhstan, Kuwait, Nigeria, Oman, Qatar, Saudi Arabia, Algeria Bahrain Comoros Djibouti Egypt Iraq Jordan Kuwait Lebanon Libya Mauritania Morocco Oman State of Palestine Qatar Saudi Arabia Somalia Sudan Syrian Arab Republic Tunis ia United Arab Emirates Yemen, Somalia, Jordan, Lebanon, Jimena, Sudan, Iraq, Kurdistan
} 
The Jakarta Post ${ }^{4}$ published a very interesting article called How COVID-19 Will Reshape Is lamic Finance Markets. Namely, it is a well-known fact that since the emergence of the Is lamic financial industry (1970s), there has been a steady increase in demand for Sharia-compliant products and services, ${ }^{5}$ and the total as sets of that industry reached USD 2.5 trillion in 2019. However, under the influence of the COVID-19 pandemic, then the instability of oil prices and the uncertain macroeconomic environment, the Is lamic financial industry is facing a challenge (but also new opportunities) unprecedented in its future development. The article clearly notes that the impact of the 2008 global financial crisis on Islamic banks and Is lamic financial institutions was largely minimal due to bans on speculation and risky asset classes in the financial industry. However, the COVID-19 pandemic will have a more serious and deeper impact on Islamic financial markets, as the currentcrisis particularly affects small and medium-sized enterprises, as well as low-income and low-wage earners.

It should also be noted that compared to the conventional economy, Is lamic finance is much more exposed to the "crown crisis", in the sectors of s mall and mediumenterprise development, microfinance and retail lending. ${ }^{6}$ Des pite government measures such as tax breaks in Indonesia and Malaysia for small and medium-sized enterprises, they are still under enormous financial pressure (given the measures to close their businesses, which in turn are imposed to prevent and further spread COVID-19).

In April 2020, UNDP highlighted several Sharia-compliant financial instruments that could be part of an integrated plan in response to a pandemic, including zakat (charity) and Sukuk (Is lamic bonds) to help countries prepare, respond and recover frompandemics.

Furthermore, Naharand \& Farhan (2020), in their paper entitled The Future of the GlobalEconomy Post COVID-19, deal with the analysis of the implications of the pandemic and the health cris is on the global financial system. The authors announce a new economic recession, much s tronger and more devastating than during World War II. In doing so, they also gave a concise screening of the entire economy. The global political and economic balance in many countries has been shaken. We note large shocks to world supply and demand, and there is also volatility in financial markets. Economic life, especially in the US and Europe, has stalled.

The IMF has downgraded its global growth forecast for 2020 due to the expansion of Covid-19. The fund estimated that the global economy, which is expected to grow by $3.3 \%$, will shrink by $3 \%$ in 2020 . The forecast of global economic growth for the next yearincreased from $3.4 \%$ to 5.8\%. According to an IMF report, the US economy will shrink by 5.9\% this year and the Eurozone by $7.5 \%$. Germany, one of Europe's leading economies, is expected to shrink by $7 \%$ and Italy, which is hardest hit, with an outbreak of $9.1 \%$ this year, the British economy will shrink by $6.5 \%$ this year. Developing countries' growth forecast down from 4.4\% to minus 1\% in 2020 (IMF World Economic Outlook, April 2020) According to Islamic economis ts, COVID-19 provides an opportunity for the so-called transformative development of Islamic finance. Cited by (IMF World Economic Outlook, April 2020)

- We expect the Islamic financial industry to show small to medium single-digit growth in 2020-2021, compared to $11.4 \%$ in 2019 , following the strong market performance of the Sukuk.

- COVID-19 offers an opportunity for more integrated and transformative growth with a higher degree of standardization, a stronger focus on the social role of indus try and a meaningful adoption of financial technology (Fintech).

- Coordination between different stakeholders is crucial for an industry that uses these opportunities for sustainable growth.

S\&P Global Ratings believes the global Is lamic financial industry will return to slow growth in 2020-2021. After strong performance in 2019, aided by a more dynamic Sukuk market, there has been a significant slowdown in basic Islamic financial economies in 2020, due to measures taken by various governments to combat the COVID-19 pandemic. ${ }^{7}$

\footnotetext{
${ }^{4}$ Available at: https://www.thejakartapost.com/academia/2020/06/05/how-covid-19-will-reshape-islamic-financemarkets.html, $20^{\mathrm{TH}}$ September 2020.

${ }^{5}$ For example: socially responsible investment, sustainability and digitalis ation, thus approaching conventional fastgrowing economies.

${ }^{6}$ Especially in Asia.

${ }^{7}$ In 2020, we expect a slowdown driven primarily by measures taken by various governments to control the COVID-19 pandemic. This slowd own will be offset to some extent by strong liquidity injections by various central banks to help their banking systems cope in a difficult environment. However, this, together with the complexity and lower appetite of investors, will contribute to the slowdown of the Sukuk market (as the primary source of financing) in 2020. Issues are projected to reach $\$ 100$ billion in 2020 compared to $\$ 162$ billion in 2019.
} 
Furthermore, there is a common opinion according to Is lamic analysts that the instruments of social Islamic financing can help Is lamic countries, banks and corporations to cope with the current situation. This primarily refers to:

- Qard Hassan - free liquidity lines for financial institutions to provide subsidized lending to their corporations and SMEclients.

- Social Sukuk - these instruments could help support the education and health systemand attract investors in the field of environment, social policy.

- Vakuf - This could help provide affordable housing solutions or access to health care and education for people who may have lost part of their income.

- Zakat - could help make up for lost household income due to COVID-19.

\section{RESEARCH METHODOLOGY}

The subject of the research, and the defined general and operational goals, determined the research procedure. Having in mind the interdisciplinary character and complexity of the set subject of research, in this paper, different methods and techniques of s cientific res earch will be used to prove the correctness of the sethypothesis. In general, general methods of scientific research are distinguished, i.e. basic methods of logical and scientific knowledge, as well as their combination, which are also appropriate to the subject of research.

In this context, the following research methods will dominate in some parts of the paper: basic methods of scientific description, collection and editing of facts, and formulation of individual statements, then methods of economic analysis and logical reasoning and understanding. The hypothetical-deductive method is a key method by which the theoretical concept of research will be formulated on the basis of exis ting scientific papers and knowledge in this field. The theoretical aspect of the research will involve the use of the method of analysis and synthesis. Methods of generalization and abstraction will be used in the theoretical part of the paper - a review of previous research, as well as in presenting research results. In addition, methods of systematized approach (holistic approach), classification and comparison will be used to present previous research, as well as the results of our own research. The method of induction will be applied in the empirical verification of hy potheses and research goals, in the context of making adequate conclu sions about the conducted research. When drawing conclusions as well, methods of analysis and synthesis will be applied.

The planned research will be based on secondary data sources. Thus, the available secondary data sources will be processed using THEDESK RESEARCH METHOD. Thus, books from the field of Islamic economics and finance, international finance in the process of globalization, articles, studies, statistical publications, magazines, bulletins, reports of domestic and world institutions, and websites of relevant international financial and other organizations stand out.

The results of the research will be presented below.

\section{ANALYSIS AND INTERPRETATION}

\subsection{Specific of Islamic financialsystemin times of COVID 19}

All types of transactions, banking products, way of investing and business approach in Is lamic banking are in accordance with the Sharia according to which it is forbidden to include interest in banking products and to perform speculative and unfair transactions. (Islamic Finance and ESG) The basic principle of Islamic finance is trans actions accompanied by productive activities with an emphasis on risk sharing in order to streng then the financial and real economy sectors, which implies discipline and responsibility of financial institutions in ensuring profits in accordance with assessed risk. The principle that defines Is lamic finance is, therefore, risk sharing which ensures economic growth, financial stability and promotes financial inclu sion by encouraging entrepreneurial ideas and opportunities.

The modern history of Is lamic finance can be observed through three periods, its emergence in the 1970s and 1980s, the period of consolidation and increasing internationalization of the 1990s and the development at the beginning of this century. Islamic finance has evolved in these periods froman alternativeeconomy on the margins of banking to recognized financial activities. Since the mid-1980s, the value of as sets managed by Is lamic finance has been about $\$ 5 \mathrm{billion}$. In the mid-1990s, that number rose to $\$ 150$ billion. Islamic finance underwent major changes and growth at the beginning of the 21 st century, reaching its peak just before the onset of the $2008 \mathrm{~g}$ lobal financial cris is. Assets managed in accordance with sharia regulations recorded a growth of $160 \%$ in the period $2009-2012 .{ }^{8}$ This growth has slowed in the last four years.

\footnotetext{
${ }^{8}$ Aavailable at: (https://www.imf.org/external/themes/is lamicfinance/, $20^{\text {th }}$ September
} 
Des pite the challenges posed by the financial crisis, the global development of Is lamic finance continues, making it one of the fastest growing financial segments in the international financial system

According to the Global Is lamic Finance Report (2018), global Is lamic financial services grew by 6.02 percent in 2017, compared to their value of $\$ 2.293$ trillion at the end of 2016. At the end of 2019, Is lamic finance was worth $\$ 2.413$ trillio $n$. Islamic finance, with a focus on profit-and-loss sharing and a ban on charging interest on financial trans actions, has been spared the worst consequences of the financial crisis. In fact, Islamic fin ance has acquired the character of a fair and more efficient alternative to the existing international banking system. Islamic finance introduces greater discipline into the financial sys temby requiring financiers to share the estimated risk, linking loans to economic growth and approving loans to buy goods and services that the seller offers to buyers who want them with certainty. Although the growth of Islamic banking and finance has slowed over the past four years, this industry will continue to grow in the long run. It is expected that by 2020 , the Mus lim population will make up 2.5 billion people, and that Islamic finance will continue to shape the global banking scene. For example, 10 out of 25 fast-growing companies are Muslim, and Muslim demographics are increas ingly shaping the market. With the growth of the middle Muslim class of consumers around the world, the halal industry has become a way of life that includes halal fashion, cosmetics, and tourismand service industries. ${ }^{9}$

Two prominent phenomena that have caused this development are the change in the mind-set of the Muslimconsumer and the rise of ethical consumeris maround the world. Although Islamic banking and finance are concentrated in the countries of the Middle East and Asia, the renewed interest of Western countries and transition countries in Africa and Central Asia represents a positive development (Has san \& Lewis (2009)). These economies have reluctantly embraced Islamic finance not only as a means of raising capital for infrastructure projects, but also as the mainstreamof retail banking, finance, and insurance.

Another positive development in Is lamic finance is the shift of focus to social goals and financial inclusion. In the light of the Arab Spring, the 2008 global financial crisis and the ongoing COVID-19 pandemic, there was a need for innovation in the service and manufacturing sectors that impacts economic creation, jobs and financial inclusion. Given social and ethical principles and an emphasis on risk-sharing and secured funding, Islamic finance represents the untapped potential of a significant and non-traditional resource that contributes to the achievement of UN self-sustaining development goals (SDGs). For example, as part of its obligations under SDGs, the Islamic Development Bank has announced that it will increase funding for ten-year SDGs activities from an initial $\$ 80$ billion to $\$ 150$ billion over the next 15 years. Despite impres sive progress, Is lamic finance as an industry continues to face several challenges. Increased transaction costs are one of the main unresolved is sues facing the Is lamic finance industry. Some would say that this is because this economy has not yet reached its full size. Others argue that the cause of this problemis a lack of legal and regulatory harmonization. Despite all the arguments, this issue requires a solid solution, es pecially in the area of home finances in many Muslim countries and communities living in non-Muslim countries (Baldwin \& di Mauro (2020)). The industry is still facing the problem of how people perceive it. Many still think that Muslims created Islamic finances for Muslims by placing them exclusively on Muslimmarkets. Although it seems so, the spirit of Islamic finance is much greater. Take, forexample, the ban on charging interest which is also part of Christianity and Judaism. It is also important to note thatcharging interest is also forbidden in Buddhism, Hinduismand many other religions and philosophies.

The gap in financial inclusion is another is sue facing Islamic finance. Although there is a high demand for Islamic microfinance services in OIS countries (Organization of Is lamic Cooperation), the services are not fully met. The study shows that, although OIS countries have more microfinance deposits and accounts per thousand adults compared to nonOIS countries, the values of MFIs (international financial institutions) deposits and loans as a percentage of GDP are still much lower in OIS countries ( 0.61 and 0.79 percent $)$ compared to developing countries ( 0.78 and 0.97 percent) and lowincome countries ( 0.92 and 1.19 percent, respectively) (Freedman, Kumhof, Laxton, Muir \& Mursula, (2010). It is therefore neces sary to create and improve innovative and diverse microfinance products to enable a poor society to thrive in this way. It is even more important to ensure fair distribution. At the same time, it would make sense to link these initiatives with certain types of ins urance as onetype of buffer of the Is la mic financial services industry.

Another challenge is the lack of Islamic monetary policies. At the macro level, the availability of Is lamic monetary instruments is necessary for the realization of the macroeconomic goals of the Is lamic financial system if, among other things, adequate liquidity management is to be ensured. Some countries have initiated the creation of these instruments, such as Indonesia and Malaysia. However, more needs to be done to facilitate both transactions and liquidity management between countries with interest-free financial systems. (Guerrieri, Lorenzoni,, Straub, \& Werning (2020). There is great potential in Is lamic finance to promote sustainable economic growth by providing various funding opportunities (including

${ }^{9}$ Available at: https://www.gfmag.com/topics/blogs/is lamic-finance-just-muslim-majority-nations, $20^{\text {th }}$ September 
microfinance), financing infrastructure projects, and expanding Islamic insurance services. In recent years, socially res ponsible investments have become increasingly desirable. The International Fund for the Financing of Immunization Companies has issued an international financial certificate (Sukuk) to fund immunization programs in the world's poorest countries through the Gavi Foundation - The Vaccine Alliance. Through the Is lamic certificate is sued by the Malaysian Khazanah as part of its sustainable and responsible investment program, revenues have been made possible to finance a "quality education" programas a basis for improving people's quality of life. Last year, Malaysia is sued the world's first green Islamic financial certificate thanks to the cooperation of the Malaysian Central Bank, the Securities Commis sion and the World Bank (Mobin \& Ahmad, (2017) The Green Sukuk will fill the gaps in green funding that are in line with the goal of "climate-related activities" and the goals of "protecting wild life and plan ts at sea and on land".

Other Is lamic financial instruments such as Zakat, Waqf, Takaful and Is lamic microfinance can serve to meet other UN sustainable development goals. Microfinance institu tions based on zakat and W aqf can be used for social programs. Vakuf real estate can generate income through their rental. The funds raised can be directed to social development programs. In the meantime, interest-free loans for the education, health and agriculture sectors can be secured with endowment cash. Microfinance insurance, on the other hand, can be an effective means of providing protection to the poor and thus contribute to sustainable poverty reduction. Financial inclusion of the poor requires a different approach in product design, pricing and payment methods. It requires innovation, flexibility, efficiency and dedicated leadership. Islamic microfinancehas yet to enter the scene to allow equal access to finance within Islamic finance. In this sense, Fintech technology enables Islamic financial institutions to reach potential clients more efficiently (Mohamed \& Ali(2018)) Fintech can help increase Islamic funding in regions where the brick-and-mortar model is not financially viable and which is tied to companies that do not offer their services online. Fintech can be a key catalyst in increasing the spread of Is lamic banking in Muslim majority countries and can help execute common Is lamic financial transactions. In addition, Fintech can also increase cross-selling Islamic banking products.

\subsection{Pandemic crisis vs. Global financial crisis: position of Islamic finance}

As the Covid-19 virus reached pandemic proportions, the clos ure of state borders and the isolation of states led to reduced consumer demand and the collapse of industrial production and service industries. The crisis has led to major financial problems for small and medium-sized enterprises (SMEs) and caused significant lay offs. In a few weeks, unemployment reached double digits. Large companies were als o not immune to the pandemic. While Boeing and major U.S. airlines have sought help from state funds in excess of $\$ 100$ billion to continue operations, several well-known companies, including Hertz, Thai Airways and JCPenney, have filed for bankruptcy.

As the Covid-19 pandemic paralyzed international trade almost to the point of stopping and devastated national economies, stock markets collapsed. The S \& P500 began to fall on February 19 and lost almost a third of its value in a month. The fall of the US stock market came to a halt and it beg an to recover partially only after the Central Bank (Fed) pledged to borrow trillions of dollars and after the US Congress granted more than \$ 2 trillion in federal emergency aid to US companies and financial institutions. Almost simultaneously, as a domino effect, stock markets in Asian markets began to fall. Along with the collapse of the U.S. stock market, Japan's Nikkei Indexand Singapore's Straits Times Indexlost about $30 \%$ of their value, while Hong Kong's Hang Seng Index fell nearly 20\%. As the global economy experienced total paralysis, Morningstar Research reported that in March 2020, investors withdrew $\$ 326$ billion from investment funds world wide.

In the midst of an unprecedented economic cris is, an often neglected area of investmenthas emerged - Is lamic investment funds. These funds avoid non-halal activities, such as: conventional finance, alcohol, gambling, pig products and adult facilities, as well as tobacco and weapons production. In addition, the selection criteria require investment in companies with low debt ratios, low cash and interest rates, low receivables and cash, as well as low revenues from prohibited activities. (Kayed \& Hass an (2011)). Primarily intended for Is lamic investors, these funds are also attractive to investors who do not take into account religious background. The fact that they avoid sectors related to arms production makes them attractive to a wider investor base, es pecially given the trend of environmental, social and managerialinvestment (ESG). Also, their conservative nature can be attractive to long-terminvestors.

During the economic panic caused by the Covid-19 pandemic in March, The MSCI World Indexlost over 30\% of its value, while The MSCI World Is lamic Index lost $20 \%$ of its value, which is relatively better result by $10 \%$. As the Is lamic index proved to be better than others on the market during the crisis, it can be said that Is lamic investment funds provided investors with a degree of protection against negative risk. It is particularly interesting that in certain countries there has been an influx of Islamic funds, although the pandemic has triggered a significant decline in managed as sets (AUM) 
worldwide. According to Fitch, Islamic funds in Saudi Arabia recorded a 3\% increase in managed assets (AUM), surpassing Malaysia as the largest market for Is lamic funds in the world. Notwithstanding the above, it is still too early for triumphant conclusions because the Covid-19 crisis has been present for a relatively short time, and the better performance of the Islamic Financial Indexprovides relatively little data to draw significantconclusions.

Although some analysts have attributed the success of Is lamic investment funds during Covid -19 to luck, we found a similar performance during another major economic downturn - the Global Financial Cris is of 2008-2009 (Cogan \& Taylor.) Although better performance of Islamic indices during the Covid-19 crisis could be the result of short-term os cillations, data for a longer period of the Global Financial Crisis provide a basis for stronger experimentation to examine the relative performance of Is lamic indices relative to conventional global indices. Approximately six months after the fall of Lehman Brothers, The MSCI W orld Index lost $42.6 \%$ of its value, while The MSCI World Islamic Index lost only $12.4 \%$ of its value, resulting in better a result of over $30 \%$.

Another significant performance meas ure over the decade around the Global Financial Cris is - from the founding of the Dow Jones Global Indexin October 2006 to December 2016 - indicates that a 100 inves tment in the Dow Jones Global Index would rise to \$123.96, while equivalent investment would in the Dow Jones Global Is lamic Index brought in \$ 144.99, which is approximately a $20 \%$ better return. Part of the difference in performance during the Global Financial Cris is stems from the avoidance of Is lamic funds investing in conventional financial institutions, and their investment in Islamic financial institutions, which has made them more conservative and resilient to adverse economic conditions. Famous are the examples of Bear Stearns, Lehman Brothers, Merrill Lynch and other giants of the financial world who filed for bankruptcy or were taken over to avoid bankruptcy. Their shareholders lost hundreds of billions of dollars. None of these conventional financial in stitutions operated in accordance with Sharia principles and were therefore not included in Islamic funds.

A study by Jemma Dridia and Maher Hassan of the International Monetary Fund suggests that Is lamic banks outperformed conventional banks during the Global Financial Cris is due to smaller investment portfolios, lower leverage and avoidance of financing or investing in innovative (and risky) instruments that ruined conventional banks. Surpris ingly, Is lamic managed assets amounted to only \$ 15 billion in 2008. Although, according to the data of the Malaysian International Islamic FinancialCentre, it increased almost five times to 70.8 billion US dollars in 2017, the projections are even more optimis tic for the future - an increase to approximately 216 billion dollars by 2024.

\subsection{Possible scenarios of economic recovery - post Covidperiod in conventional and Islamic economy}

Economis ts analyse the current COVID-19 scenario and predict four possible models of economic recovery, as follows. In the shape of the letter $\mathrm{V}$, means when the closure is completed and a quick return to economic normalcy. This option is pos sible, but difficult to realize because, as mentioned earlier, the world will not return to the same economic scenario as before the pandemic. Security meas ures, limited capacity, closed borders and fear of infection play against this possibility. Ranasinghe \& Carvalho (2020) explained that the V-shaped recovery model is the best outcome. Similarly, a rapid recovery follows the collapse of production. "GDP cuts from April to June are likely to be on a scale we haven't seen in decades. But a fis cal and monetary stimulus - over $\$ 10$ trillion and counting - could help an equally rapid recovery." Ross W alker, head of NatWest Markets' global economy, estimates that the economic downturn is expected in this quarter "with a significant jump in Q3 and Q4 as businesses reopen." 
Figure 1: First s cenario: V-shaped recovery

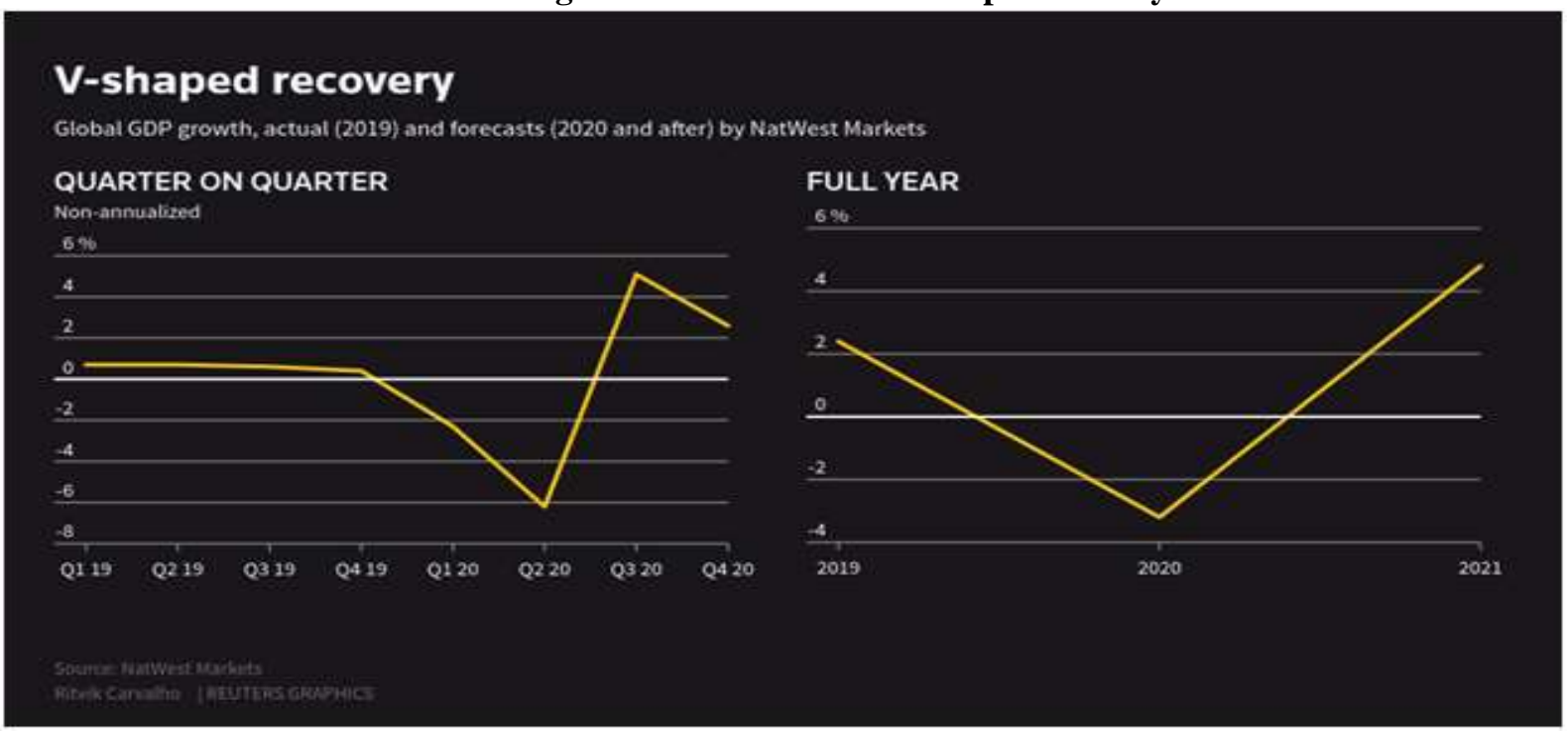

Source: $\underline{\text { https://insamer.com/en/the-future-of-global-economy-post-covid-192980.html }}$

https://fr.reuters.com/article/health-coronavirus-economy-idUSL8N2BW4ZJ

The U-shaped option means that it will take more time to return to economic normalcy. This formof recovery seems to be in line with the situation we will encounter after closure, bec ause the opening will be progressive, and the situation will be different from the one before the appearance of the coronavirus. Ranashighe \& Carvalho (2020) argued, "Economies experienced a recession faster and deeper than 2008-09. Given this situation, they predicted that this could be the most likely outcome." Although almost all organisms agree that a U-shaped recovery is the most likely, some warn of a less fav ourable scenario. The U-s hape is a basic case for ING's Brzeski, who notes that the impact of locks will last for some time after they are lifted. "The easing of locking measures will be gradual, social dis tancing will continue, and the tourism indus try is likely to continue to suffer," Brzeski said.

\section{Figure 2: Secondscenario: Ushaped recovery}

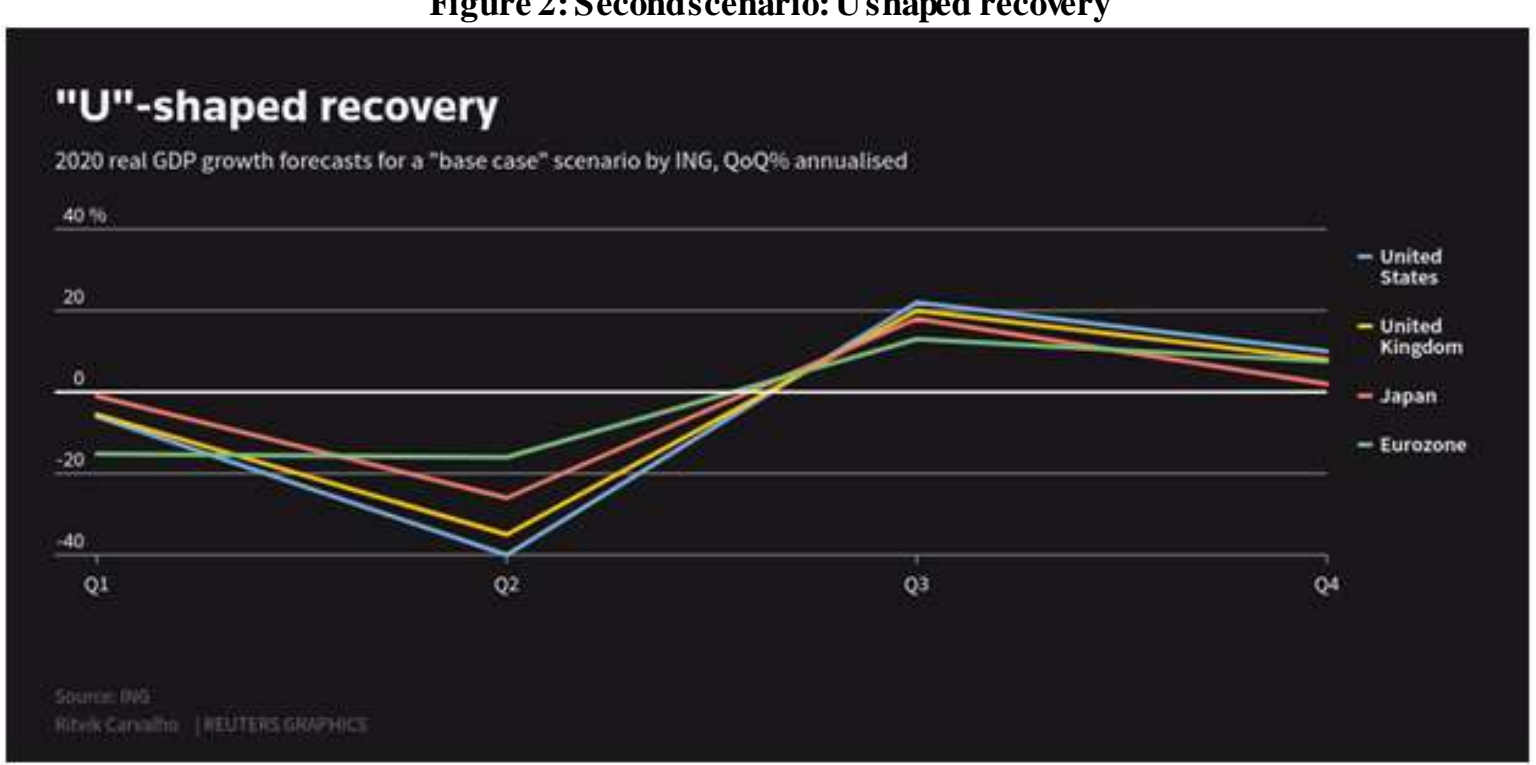

Source: https://insamer.com/en/the-future-of-global-economy-post-covid-19 2980.html https://fr.reuters.com/article/health-coronavirus-economy-idUSL8N2BW4ZJ

In the formof the letter W or Double-dip, this means that, after a slight recovery, there would be a decline again, and then a final economic recovery. This option is in line with the outbreak or disappearance of the initial effect of monetary and fiscal meas ures es tablis hed in the fight against coronavirus. According to Ranasinghe \&Carvalho(2020), if easing the lock 
restrictions would initially boost activity, the effects of unemployment and corporate bankruptcies would begin to filter out.

Figure 3: Third scenario: W shaped recovery

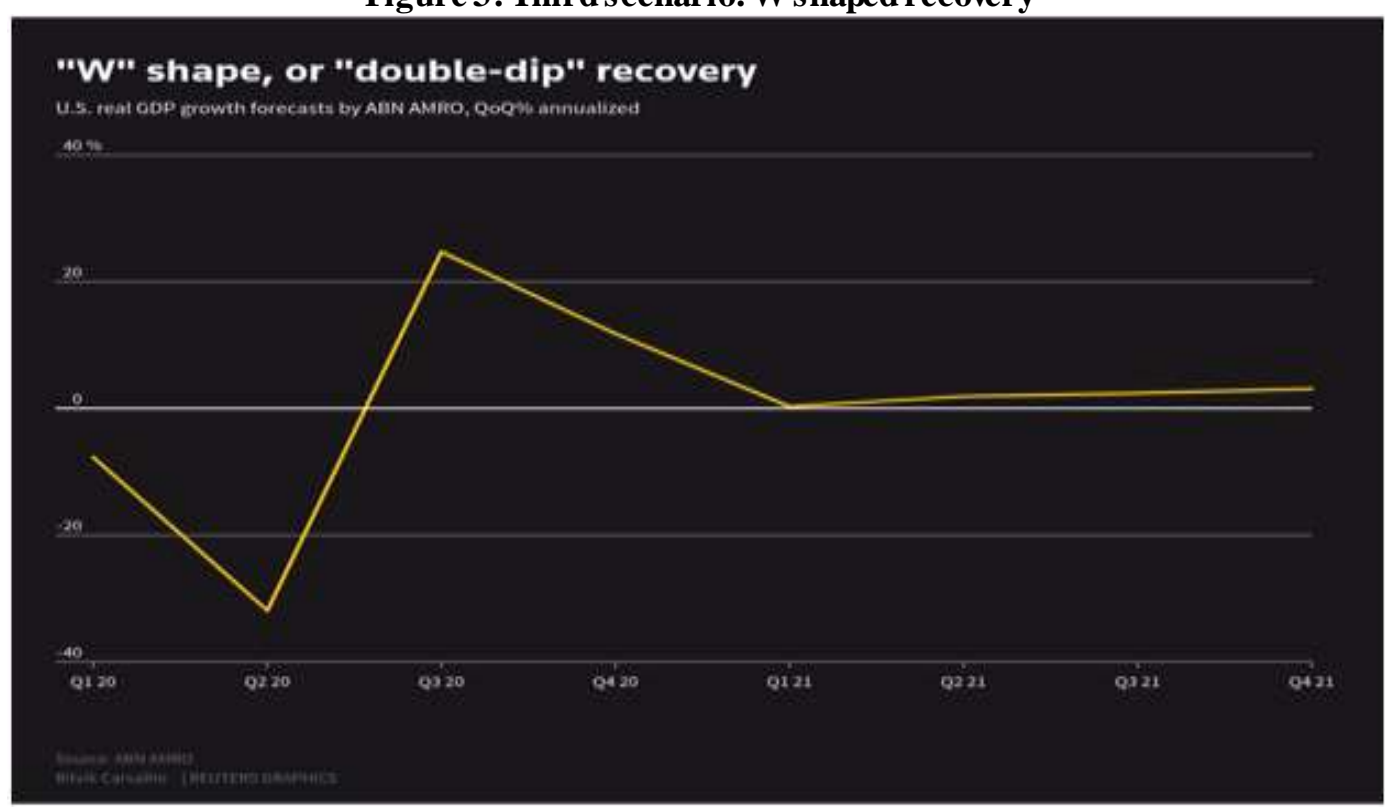

Source: $\underline{\text { https://insamer.com/en/the-future-of-global-economy-post-covid-19 2980.html }}$ https://fr.reuters.com/article/health-coronavirus-economy-idUSL8N2BW4ZJ

L-shaped, this is the worst option we could face. That would mean that we will go through a great crisis that should takea long time to recover. This is the blackest economic scenario and implies strong economic and social changes, which always happens when there is a major economic collapse. Accordingly, Ranasinghe \& Carvalho (2020) explained, "L-s haped outcomes may pose a risk to those emerging markets that are less able to engage a large stimulus and often rely on commodity exports."

\section{Figure 4: Fourth scenario: Lshaped recovery}

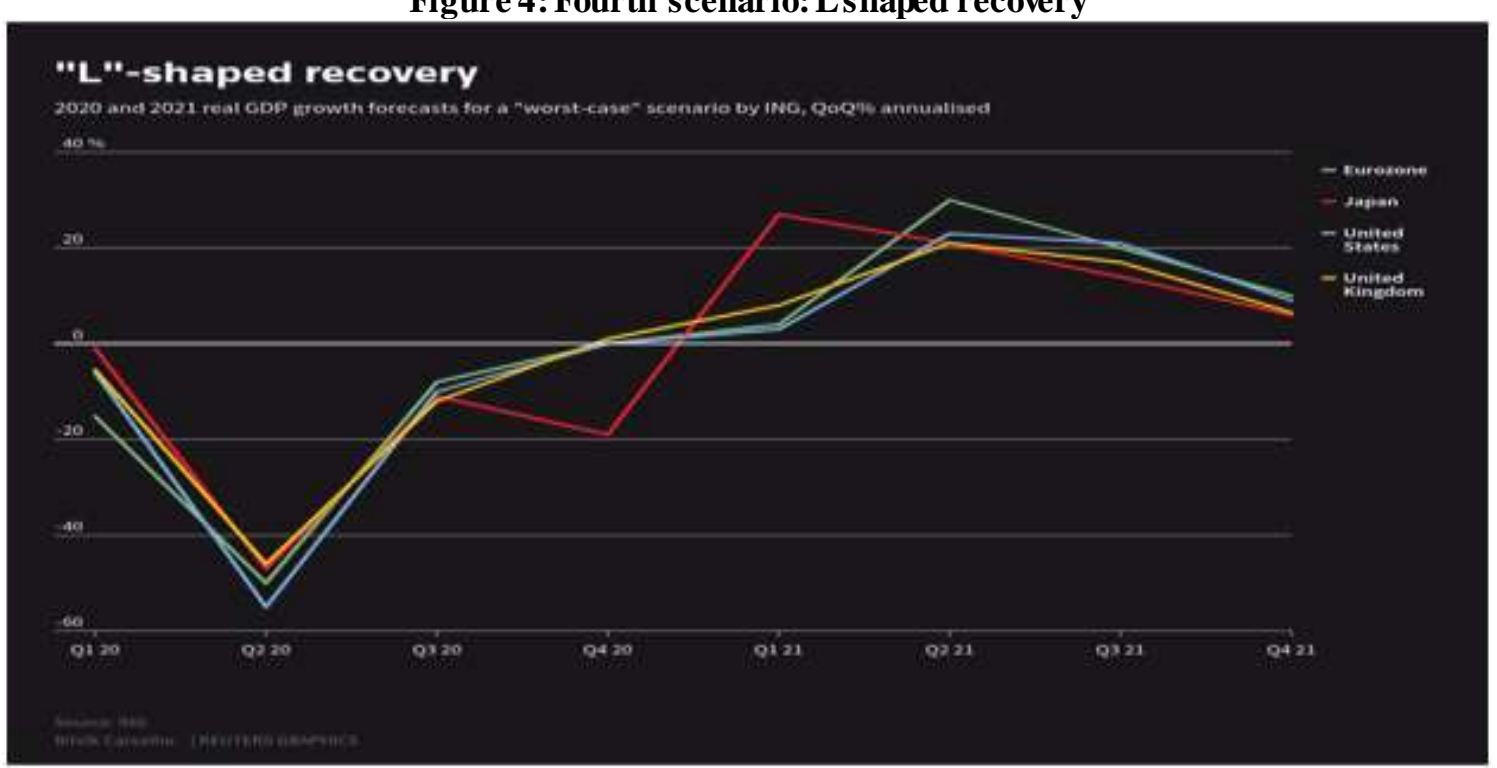

Source:

https://insamer.com/en/the-future-of-global-economy-post-covid-19 2980.html

https://fr.reuters.com/article/health-coronavirus-economy-idUSL8N2BW4ZJ

As can be argued, "recovery of normalcy" is a relative term, where it is impos sible for us to return to a pre-pandemic state without vaccines or expanded immunity. When the closure is over, the return to economic normalcy will be gradual. Everything would be imposed between great hygiene and s afety measures, avoiding crowds and checking infections from 
week to week to avoid regrowth. These meas ures will be a major challenge for many businesses, with limited capacity in restaurants and bars, concert halls, museums, universities, schools, etc., with their impact on business results. Finally, various studies show that biodiversity loss and ecosystem destruction are associated with increased transmission of infectious diseases. In recent years, we have experienced the proliferation of recurrent diseases such as COVID-19, MERS, Ebola, as well as SARS. In short, as soon as we overcome this crisis, we must learn and work both in terms of potential preventive measures against the pandemic and in improving sustainable economic development before it is too late.

\section{CONCLUSION AND RECOMMENDATIONS}

Islamic inves tmentfunds can provide some protection against adverse risk as evidenced by their better performance during two major crises. This is partly due to limited exposure to high-risk financial instruments, such as those of conventional financial institutions. These return on investment characteristics should be attractive not only to Islamic investors, but also to the general public.

Also, Moody's "2020 Investors Service's Report" predicts an increase in Islamic as sets by 3 to $4 \%$ per year in the short and medium term. The report states that the demand for Islamic asset management is growing due to the "large Muslim population, favourable legis lation and the growing demand of investors for products that comply with Sharia principles." We expect that these facts will further encourage the development of the Islamic as set management industry and thus expand the existing world of investment.

A study by JemmDridia and Maher Hassan of the International Monetary Fund suggests that Is lamic banks outperformed conventional banks during the Global Financial Crisis due to s maller inves tment portfolios, lower leverage and avoidance of financing or in vesting in innovative and risky instruments that ruined conventional banks. Surprisingly, Islamic-managed as sets amounted to only \$15 billion in 2008. Although, according to the data of the Malaysian International Is lamic Financial Center, it increased almost five times to 70.8 billion US dollars in 2017, the projections are even more optimistic for the future - an increase to approximately 216 billion dollars by 2024 .

Islamic finance is a factor of stability in times of challenge. However, the assets of Is lamic banks are estimated at about two trillion dollars, and Is lamic finances are still low compared to the conventional financial market. Nevertheless, by adapting financial instruments to modern trends, it is possible to achieve an even greater reach of Islamic finance. In an environment that is generally unfamiliar with the concept of Is lamic banking, Islamic finance has managed to establish itself, be recognized as supporting the growth and development of the entire community, and achieve continuous growth over the last decade.

Great potential for growth of this sector is es pecially in developing countries, integration of Is lamic and halal industry, as well as new technologies and FinTech. The slow growth of Is lamic finance could be overcome by the implementation of large infrastructure projects in less developed countries. Islamic banking traditionally offers products that protect their customers. However, at a time of paradigm shift towards block chain technologies, crypto currencies, FinTech services, which are new and relatively unknown to customers, Islamic banking needs to adapt to these modern trends

\section{REFERENCES}

[1] Baldwin, R., \& di Mauro, B. W. Mitigating the COVID economic cris is: Act fast and do whatever it takes. Vox Eu. Org, CEPR, 2020. Pp 1-213

[2] Cogan, J. F., \&Taylor, J. B. What the government purchases multiplier actually multiplied in the 2009 stimulus package (No. w16505). National Bureau of Economic Research, 2010.pp 1-33

[3] Dhrara Ranasinghe, Ritvik Carvalho, "Alphabet soup: How will post-virus economic recovery shape up?" Accessed on June 1, 2020. Available at: https://uk.reuters.com/article/uk-health-coronavirus-economy-graphic/alphabet-soup-howwill-post-virus-economic-recovery-shape-up-idUKKCN21R25J?il=0, 10 September

[4] Freedman, C., Kumhof, M., Laxton, D., Muir, D., \& Mursula, S. Global effects of fiscal stimulus during the crisis. Journal of monetary economics, 2010, 57(5), pp. 506-526.

[5] Guerrieri, V., Lorenzoni, G., Straub, L., \& Werning, I. Macroeconomic Implications of COVID-19: Can Negative Supply Shocks Cause Demand Shortages? (No. w26918), 2020. National Bureau of Economic Research.pp.1-36

[6] Has san, K., \& Lewis, M.(Eds.). Handbook of Is lamic banking. Edward Elg ar Publishing. 2009

[7] https://www.thejakartapost.com/academia/2020/06/05/how-covid-19-will-reshape-islamic-finance-markets.html. $20^{\text {th }}$

September

[8] https://insamer.com/en/the-future-of-global-economy-post-covid-19 2980.html20 $20^{\text {th }}$ September 
[9] https://fr.reuters.com/article/health-coronavirus-economy-idUSL8N2BW4ZJ20 $0^{\text {th }}$ September

[10] https://www.sesric.org/publications-detail.php?id=50420 $20^{\text {th }}$ September

[11] https://www.arabstates.undp.org/content/rbas/en/home/coronavirus.html $20^{\text {th }}$ September

[12] https://reliefweb.int/report/world/impact-covid-19-middle-east-and-north-africa, $20^{\text {th }}$ September

[13] https://www.aa.com.tr/en/economy/islamic-finance-body-sets-up-fund-on-coronavirus-impact/1769145, $\quad 20^{\text {th }}$

September

[14] https://www.nordeatrade.com/en/explore-new-market/saudi-arabia/economical-context, $20^{\text {th }}$ September

[15] http://www.oecd.org/economic-outlook/march-2020/\#resources $20^{\text {th }}$ September

[16] https://www.imf.org/en/Topics/imf-and-covid19/Policy-Responses-to-COVID-19, 20 ${ }^{\text {th }}$ September

[17] $\quad$ https://www.imf.org/external/themes/islamicfinance/, $20^{\text {th }} \quad$ September

https://www.gfmag.com/topics/blogs/islamic-finance-just-muslim-majority-nations, $20^{\text {th }}$ September

[18] IMF W orld Economic Outlook. (April 2020). the Great Lockdown. World Economic Outlook Reports. Accessed on June 3, 2020. Available at:https://www.imf.org/en/Publications/WEO/Issues/2020/04/14/weo-april-2020, 10 September

[19] Investors Service's Report available at:

https://www.spglobal.com/ assets/documents/ratings/research/islamic finance 2020 screen.pdf, $20^{\text {th }}$ September

[20] Islamic Development Bank available at: https://www.is db.org/, $20^{\text {th }}$ September

[21] Islamic Finance AndESG: Sharia-Compliant Instruments Can Put TheS In ESG, May 27, 2020

[22] Is lamic Finance Development Report 2019. Global Is lamic Finance. Industry Landscape. Islamic Finance Assets Growth 2012 - 2018 available at: $\underline{\text { https://icdps.org/uploads/files/IFDI\%202019\%20DEF\%20digital1574605094_7214.pdf }}$ $20^{\text {th }}$ September

[23] Jamshaid Anwar Chattha the Covid-19 Pandemic: Supervis ory Implications and Priorities for Islamic Banking, TORONTO Centre, 2020 pp.1-23

[24] Kayed, R. N., \& Hassan, M. K. The global financial crisis and Is lamic finance. Thunderbird International Business Review, 53(5), pp. 551-564, 2011

[25] Lutfun Naharand, Naimul Islam Farhan. The Future of Global Economy Post COVID-19, 2020 available at: https://insamer.com/en/the-future-of-global-economy-post-covid-19 2980.html20 ${ }^{\text {th }}$ September,

[26] Mobin, M. A., \& Ahmad, A. U. F. Achieving sustainable economic development through Is lamic microfinance and the potential of a proposed two-tier Mudarabah Waqf business model. In Handbook of empirical research on Islam and economic life. Edward Elg ar Publishing, 2017

[27] Mohamed, H., \& Ali, H. Block chain, Fintech, and Islamic finance: Building the future in the new Islamic digital economy. Walter de Gruyter GmbH \& Co KG.,2018

[28] OECD Economic Outlook Interim Report Corona virus: the world economy at risk (March 2020)

[29] OIC Economic Outlook 2019 Statistical, Economic and Social Research and Training Centre for Islamic Countries SESRIC

[30] Organization of the Is lamic Conference available at: https://www.oic-oci.org/20

[31] UNDP (2020), Islamic finance takes on COVID, UNDP available at: https://www.undp.org/content/undp/en/home/blog/2020/is lamic-finance-takes-on-covid-19.html, 20 ${ }^{\text {th }}$ September 